\title{
FACTORS AFFECTING THE WORK LIFE BALANCE: STUDY AMONG THE TEACHERS OF A GOVERNMENT SCHOOL IN SRI LANKA
}

\author{
Sareena Umma M. A. $G^{\mathrm{a}}$, Fathima Zahana M. $\mathbf{M}^{\mathrm{b}}$ \\ ${ }^{a, b}$ Department of Management, \\ Faculty of Management and Commerce, \\ South Eastern University of Sri Lanka, Sri Lanka
}

\begin{abstract}
The work life balance concept attracted by various researches and scholars, it is a trending topic to achieve the organization success today. Hence the organizations are using quality human resource and their work life balance for this purpose. Therefore work-life balance is important not only for employees' also employers too. Because work life imbalance leads to dissatisfaction in life as well as in workplace. The objective of the study is to assess the factors affecting work life balance of school teachers, for this purpose the study selected three important variables through literature review suit to the study context. Accordingly, workload, social support, childcare was selected as the factors of work life balance as independent variables and work life balance was selected as dependent variable. The researchers used a structured questionnaire to collect the primary data using population study technique. It was possible to collect 82 responses and this data used to analyze the reliability, descriptive statistic, correlation and regression analyses. The results of the analysis found that a negative relationship between workload, childcare with work life balance, also a strong positive relationship found between social support and work life balance. The multiple regression analysis disclosed that 57\% variation of work life balance explain by these three variables together. The result of the research will be helpful for the school administrators, to identify the importance of work life balance in order to improve the outcome of their schools.
\end{abstract}

Keywords: workload, social support, childcare, work life balance, government school teachers

\section{Introduction}

The overall aim of human resource management (HRM) is to ensure that an organization is able to achieve success through people. The employees who are working in an organization individually and collectively Human resources are the most valuable and unique assets of an organization to create performance. Performance of employees affected by many factors in which work life balance is one of it. Work life balance (WLB) plays an important part in shaping employees attitude towards their work and also life (Omar, Mohd \& Ariffin, 2015). Work life balance includes successfully managing the arrangement between paid work and non-paid activities, such as spending time with family, participating in exercises and leisure, offering contribute to the achievement of its objectives. The human resource management efficiently utilizes its workforce in order to achieve an organization's goals and objectives. That is why HRM selects and retains the most appropriate work force within the organization.

unpaid assistance or pursuing additional study. Enhancing balance between work and personal lives results in genuine paybacks for both employers and employees (Fapohunda, 2014).

Personal and organizational goals can be achieve through a good balance in work and life. The imbalances of work life and family life have a negative impact in the personal life of working people, thus, creating a balance between work and life is very important (Bannur \& Patil, 2015). 
In the dynamic economic environment, human resource management is assuming greater significance than ever before. It is conceived to be different from the traditional and conventional notion of personnel management (Kanthisree, 2013). The situational definition of work-life balance allows for an individual to define work-life balance based on their own satisfaction and positive functioning in both work and personal roles (Reiter, 2007). Work life balance has been described as the balance between work and all other life activities that occur outside of work.

Work-life balance not consider to giving equal time and energy to paid and non-paid responsibilities, but in its broad sense, it is a satisfactory equilibrium between work related and non-work related responsibilities (Clarke, Koch and Hill, 2004). The word work-life balance is sometimes considered as interwoven with work family conflict. However, it can be argued that the latter is more limited in scope than the former because the focus in workfamily conflict is more on the relations between work \& family. It is also referred to as family friendly work practices and in international literature, as alternative work arrangements (Kanthisree, 2013).

Two types of conflict exist; family and life interference with work and work interference with ones' life and family, respectively, reflecting the potential for the life and family domain to interfere in the work role and the work domain to interfere in the family role (Frone, 2003). Compared to life and family interference with work, work interference with life and family is more prevalent and more likely to be influenced by workplace factors (Anderson, Coffey \& Byerly, 2002).

There are a number of factors affecting work life balance of employees. According to Poulose and Sudarsan (2014), the study of work life balance: a conceptual review, on which the study identified main four factors of WLB: individual factors, organizational factors, societal factors and other factors, in which personality, well-being and emotional intelligence are individual factors. The organizational factors are work arrangements, work life balance practices and policies, organization support, superior support, colleague support, job stress, role conflict, role ambiguity, role overload and technology.
Societal factors include child care arrangements, spouse support, family support, social support, personal and family demands, dependent care issues and family quarrel. Other factors are age, gender, marital status, parental status, experience, employee level, job type, income and type of family.

Work life balance of teaching professionals has become one of the greatest issues in today's world. Teachers work load not only demands their time in the institution but also extends to their home, so as to get prepared for the following day, apart from maintaining student records and attending to various institutions related functional requirements. Teachers need to spend extra hours every day to be effective and productive in their profession so that they could reach the higher expectations and face the challenging atmosphere (Padma \& Reddy, 2013). Moreover, teachers not only look forward towards teaching, but need to also focus on soft skills and life skills so that they not only produce good individuals but also develop good citizens. Among the antecedents of work life balance most of the studies covered the individual and organizational factors, there is a few studies relevant to the societal factors (Poulose \& Sudarsan, 2014), therefore this study considered two important societal factors with one organizational factor. Hence, this study focused "factors affecting the work life balance: study among the teachers of a government school in Sri Lanka".

\section{Problem Statement}

According to Kanthisree (2013), managing a home while raising young children when both spouses are employed outside the home is challenging and stressful. Balancing one's work responsibilities and desires with one's responsibilities and interests outside work is, at best, challenging. While balancing work commitments with life commitments involves a myriad of trade-offs for two-income families with children, it also provides ongoing challenges for adults who remain single or do not have children. Mid-life workers often deal with balance issues from two ends of the spectrum; young children and ageing parents (Padma \& Reddy, 2013). This issue, however, includes employees beyond those who have children. Many employees are choosing to stay unmarried, but still have critical and valuable commitments outside work. Therefore, there is 
a need to identify the factors affecting the work life balance of school teachers. Thus this research focused the research problem as "what are the factors affecting the work life balance of school teachers?"

\section{Research Question}

1. What are the important factors affecting work life balance of school teachers?

2. What is the relationship between the important factors (work load, social support and child care) and work life balance of school teachers?

3. What are the influences of important factors (work load, social support and child care) on work life balance of school teachers?

\section{Objectives of the study}

Specifically, this study intended to achieve the following objectives:

1. To identify the important factors affecting work life balance of school teachers.

2. To find out the relationship between the important factors (work load, social support and child care) and work life balance of school teachers.

3. To evaluate the influence of important factors (work load, social support and child care) on work life balance of school teachers.

\section{Significance of the Study}

Work-Life balance has been considered of crucial importance in many public and private sector undertakings for establishing and sustaining a productive work culture. Therefore this study will be significant in a number of ways:

The study will be significant for the academics, researchers and organizations. The study contributes to existing body of knowledge by providing an insight into relationship existing between work load, social support and child care and work life balance of school teachers.

The study will help other individuals to prove the theory and also support the future research, generates good ideas and provide better understanding.
The study will help to get awareness about the issues and problems faced by employees to maintain a healthy work life balance among them thus ultimately enhance organizations' effectiveness and efficiency.

This study can support the management to improve the employees' work life balance in the future as well as to increase employees' performance.

\section{Literature Review}

\section{Work - Life Balance}

Human resource management can be considered as one of the most vital functional areas of management and the human resource is a source of competitive advantage for an organization. Therefore, every organization is very keen to utilize its human resource in an efficient and effective manner to achieve their intended goals and objectives (Opatha, 2009).

Work life balance is a growing concern all over the world in the dynamic business environment. Many researchers found out that there are interactions between family life and work life and have conducted number of researches on work-family balance in the recent past (Perera \& Opatha, 2014).

According to Grzywacz and Carlson (2007), work-family balance is an omnipresent factor in contemporary organizations and society. Unfortunately, theoretical and conceptual development of work-family balance has not kept pace with popular interest.

Due to demographic and workplace changers such as: transformation in family structures, growing reluctance for 'long number of hours' acceptance culture, greater number of women in the workforce and technological advancement. All these may result in the employees having difficulty in prioritizing between their work roles and their personal lives (Obiageli et al, 2015).

There is lack in universally accepted definition for work life balance. According to Wheatley (2012), work-life balance is the ability of individuals, regardless of age, or gender, to combine work and household responsibilities successfully. Caven and Raiden (2010) define work-life balance as individual's ability to maintain a satisfactory equilibrium between 
work and non-work life obligations. It is, however, pertinent to note that work-life balance does not mean allotting an equal amount of energy and time to both work related and non-work related life responsibilities (Osoian, Lazar \& Ratiu, 2011).

\section{Factors of Work-Life Balance}

There are many factors that affect the performance of employees, and one of which is the balance of life. Work-life balance plays a crucial role in shaping employees attitude towards their organizations and also life (Omar, Mohd \& Ariffin, 2015).

Poulose and Sudarsan (2014) identified factors of WLB are individual factors, organizational factors, societal factors and other factors. In which personality, well-being and emotional intelligence are individual factors. The organizational factors are work arrangements, work life balance practices \& policies, organization support, superior support, colleague support, job stress, role conflict, role ambiguity, role overload and technology. Societal factors include; child care arrangements, spouse support, family support, social support, personal \& family demands, dependent care issues family quarrel. Other factors are age, gender, marital status, parental status, experience, employee level, job type, income and type of family.

Reddy, Vranda, Ahmed, and Siddaramu, (2010) considered factors such as the size of family, the age of children, the work hours and the level of social support impact the experience of work family conflict and family work conflict. However, these variables have been conceptualized as antecedents of work family conflict and family work conflict, it is also important to consider the consequences these variables have on psychological distress and wellbeing of the working women.

According to Fernando and Sareena Umma (2016) there is a significant relationship between work life balance factors such as; child care, working hours, and support system and work life balance of married working women, according to the regression analysis there is a significant combined relationship between child care, working hours, support system and work life balance of married working women.
Emotional intelligence, job engagement, technology advancement and work overload are the factors affecting work life balance (Kumarasamy, 2016). Social media usage also is a factor that impact on work-life balance (Kumar \& Priyadarshini, 2018). Emotional intelligence, time management, nature of the spouse, awareness, and organizational support have positive impact on work-family balance and work stress has negative impact on workfamily balance (Samson \& Sareena Umma, 2019). Further child care responsibility, elderly dependency are negative association with the work-life balance and partner or spouse support, colleague support and job resources are positive connection with WLB, but number of working hours does not have a significant impact with the work-life balance of Sri Lankan academics (Pathiranage \& Pathiranage, 2020).

Based on the above evidences, various factors affect the work life balance, but the primary interest of this research was the dependent variable of work life balance. Therefore three independent variables were used in an attempt to explain the variance in work-family balance of school teachers in the Sri Lankan context. Based on this, the study identified workload, social support and childcare are the most relevant important factors of work life balance in the study context and considered as independent variables and work life balance was dependent variable of this study.

\section{Relationship between factors of WLB and work life balance}

\section{Workload and WLB}

Specifically work load is one of the major factors that was said to influence work-life balance. Work overload describes a perception that one has too much to do (Leiter \& Schaufeli, 1996). Individual who perceive their workload to be more than they can handle are likely to experience exhaustion and fatigue, which may negatively influence one's motivation to respond to the demands of other domains (i.e. friends and family) (Aryee, Srinivas \& Tan, 2005). Furthermore, experience shows that when employees are overworked they actually do not produce extra output. In fact, when 
employees were overloaded with work, they often get frustrated that their work-life balance seems to be missing (Vogel, 2012). According to Omar, Mohd and Ariffin (2015) the finding of the study revealed that, workload was the most dominant factor affecting work-life balance, followed by role conflict. It also showed that all of the two factors were significantly and negatively related with employees' work-life balance. These results explained that the higher workload and role conflict felt by the employees, the lesser the work-life balance enjoyed by them. Thus, employees' work-life balance can be improved by considering the amount of workload given to them as well as their feeling of role conflict in performing the job.

\section{Social support and WLB}

The social support is the availability of helping relationships and increasing the quality of those relationships (Leavy, 1983). Social support can be divided into two facets such as organizational support and family related support (Brough \& Pears, 2004). Work related social support comes from the organizational members, such as peers and supervisors, where an employee works, whereas personal social support comes from spouse, parents, children, extended family or friends. However, researchers found that support from the husband was positively associated to curb out conflict in the wife's roles (Aryee, 1992). Work-life balance is not only the responsibility of the employees, but also of the employers. Organizations also must take care of their employees by helping them maintaining a healthy balance between their personal and professional life. In other words, organizational must provide the needed support for the employees to maintain work-life balance. Organizational support is important because providing support means that firms value the contribution of their employees and cares for their employee's wellbeing (Eisenberger, Huntington, Hutchison, \& Sowa, 1986). Organizational support is important in maintaining a good work-life balance. Organizations that did not understand the importance of work-life balance might abuse their employees' hard work and effort. On the other hand, organizations that care about the well-being of their employees would show support by implementing program and policies that emphasize on work-life balance (McCarthy, Cleveland, Hunter, Darcy, \& Grady, 2013). According to Padma and Reddy (2013), the study of impact of child care responsibility on work life balance of school teachers. The study found that the demographics of the children (Age and Number of Children) have no significant influence on the work life balance of school teachers. But there is a statistically significant impact of support in child care responsibilities from spouse and elder parents on work life balance of school teachers. Hence it is concluded that school teachers need the support to share child care responsibility. If the family members are cooperative enough to give a helping hand can rightly balance the work and personal life. Similarly schools can help their teachers by providing child care facilities like crèche at work place to enable the teachers rightly balance work and family life.

\section{Childcare and WLB}

Various studies have suggested that family related factors such as number of children and childcare responsibilities lead to imbalance in work and family roles. Fathers experienced stress in child caring during the absence of employed wives from home (Gerson, 1993). Elliott (2003) investigated on major difficulties faced by the employed parents of small children particularly of age below six years, in providing adequate child care. Additionally, child care as well as care for elderly, imposes more emotional burden on females compared to males. Ross and Mirowsky (1988) showed that employed mothers finding difficulties in child-care arrangements experienced high depression.

\section{Conceptual framework of the study}

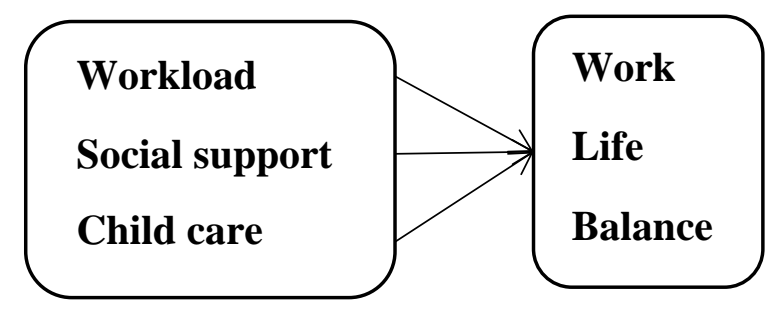

Figure 01: Conceptual Framework (Source: Developed for this study)

In this research, researchers attempt to identify the factors affecting the work life balance. Based on the review of literature and interview with the sample of the study the conceptual framework identified three variables such as 
workload, social support and child care are independent variables and work life balance is the dependent variable.

\section{Hypotheses}

Based on the conceptual framework the following hypotheses were formulated for this study.

H1: There is a negative relationship between workload and WLB.

$\mathrm{H} 2$ : There is a positive relationship between social support and WLB.

H3: There is a negative relationship between child care and WLB.

H4: The factors of work life balance (workload, social support and childcare) have impact on WLB.

\section{Methodology}

This study focused the primary data and applied quantitative methodology; therefore, the survey method has been adopted. Structured questionnaire was used to collect the data necessary to meet the objectives of the study. The questionnaire was developed with the support of previous studies relevant to these areas. Specifically the work life balance questionnaire which was developed by Swarnalatha (2013) was adopted for this research. There were two parts which consist of 44 statements, the first part included the demographic information which included age, gender, educational level and experience. The second part included the research information relating to independent and dependent variables and the questionnaire had been presented in five point Likert scale.

The study focuses on finding out the factors affecting the work life balance of school teachers in a government school in Sri Lanka. 92 teachers were selected by using population study technique, of which it was able to collect 82 responses.

Collected data were presented using tables. Meanwhile descriptive, correlation and regression analyses were used. Under the descriptive analysis, mean and standard deviation derived, correlation coefficient derived for correlation analysis and regression analysis $\mathrm{R}^{2}$ and adjusted $\mathrm{R}^{2}$ were derived.
Statistical package of SPSS 20.0 version has been used for this purpose.

\section{Result and Discussion}

The study provides the findings and discussion on factors affecting the work life balance of school teachers, in order to meet the objectives of this study. The reliability test was done for the instruments. The Cronbach Alpha value for all variables more than 0.7 , it means the reliability of the instruments in the satisfactory level.

Table 01: Descriptive Statistics

\begin{tabular}{|l|l|l|l|}
\hline Variables & Mean & $\begin{array}{l}\text { Standard } \\
\text { Deviation }\end{array}$ & N \\
\hline Workload & 3.5183 & .60881 & 82 \\
\hline Social support & 3.3951 & .74451 & 82 \\
\hline Childcare & 3.7695 & .32837 & 82 \\
\hline WLB & 3.2951 & .65469 & 82 \\
\hline
\end{tabular}

Source: Survey data

According to table 1, the mean value of workload and childcare falls to the range $3.5 \leq \mathrm{X} \leq 5.0$ the level is high, social support and WLB falls to the range $2.5 \leq \mathrm{X} \leq 3.5$ the level is moderate. It means selected employees have sufficient level of work life balance.

Table 02: Correlation Table

\begin{tabular}{|l|l|l|}
\hline Variables & 'r' value & Sig. level \\
\hline $\begin{array}{l}\text { Workload and } \\
\text { WLB }\end{array}$ & $-.361^{* *}$ & 0.010 \\
\hline $\begin{array}{l}\text { Social support and } \\
\text { WLB }\end{array}$ & $.691^{* *}$ & 0.000 \\
\hline $\begin{array}{l}\text { Childcare and } \\
\text { WLB }\end{array}$ & $-.377^{* *}$ & 0.000 \\
\hline
\end{tabular}

Source: Survey data

According to the table 2, the result of the correlation analysis revealed that there was a weak negative correlation between workload and WLB $(\mathrm{r}=-0.361)$, childcare and WLB( $\mathrm{r}=-$ 0.377 ) and a moderate positive correlation between social support and WLB ( $\mathrm{r}=0.691)$. It indicated when the workload of employees' increases the work life balance can decrease and when the childcare responsibility increases the work life balance will decrease. On the other hand, if the social support (spouse support, family support and supervisory 
support) increases the work life balance also increase.

\section{Multiple Regression Analysis}

Table 03: ANOVA

\begin{tabular}{|l|l|l|l|l|l|}
\hline Model & $\begin{array}{l}\text { Sum of } \\
\text { Squares }\end{array}$ & df & $\begin{array}{l}\text { Mean } \\
\text { Square }\end{array}$ & F & Sig \\
\hline Regression & 20.405 & 3 & 6.802 & 37.068 & 0.000 \\
\hline Residual & 14.313 & 78 & .183 & & \\
\hline Total & 34.718 & 81 & & & \\
\hline
\end{tabular}

Source: Survey data

The multiple regression analysis was conducted to determine the combine impact of workload, social support and childcare on work life balance. The table 3 shows that $F$ value is 37.068 and overall model is significant at the 0.000 level. Hence it can conclude that, there was a significant impact of childcare, social support and workload on WLB.

Table 04: Coefficients

\begin{tabular}{|l|l|l|l|l|l|}
\hline \multirow{2}{*}{ Model } & \multicolumn{2}{|c|}{$\begin{array}{c}\text { Unstandardiz } \\
\text { ed } \\
\text { Coefficients }\end{array}$} & $\begin{array}{c}\text { Standa } \\
\text { rdized } \\
\text { Coeffic } \\
\text { ients }\end{array}$ & T & Sig. \\
\cline { 2 - 6 } & B & $\begin{array}{c}\text { Std. } \\
\text { Err } \\
\text { or }\end{array}$ & Beta & & \\
\hline (Constant) & 3.854 & .650 & & 5.930 & .000 \\
\hline Workload & -.021 & .088 & -.019 & -.238 & .000 \\
\hline $\begin{array}{l}\text { Social } \\
\text { support }\end{array}$ & .582 & .069 & .662 & 8.424 & .000 \\
\hline Childcare & -.653 & .151 & -.328 & -4.320 & .000 \\
\hline
\end{tabular}

Source: Survey data

According to table 4 the multiple linear regression equation shows that $\beta$ equals to $0.021,0.582$, and -0.653 . The value of " $a$ " is 3.854; the equation can be derived as:

$$
W L B=3.854-0.021 X_{1}+0.582 X_{2}-0.653 X_{3}
$$

Based on the table 5, the Adjusted R Square is 0.572 and $\mathrm{R}^{2}=58 \%$, if $\mathrm{R}^{2}>50 \%$, then the model has a good fit, since adjusted $\mathrm{R}^{2}$ is $57.2 \%$, which indicates $57 \%$ of the variability in WLB is explained by childcare, social support and workload together.
Table 05: Model summary

\begin{tabular}{|l|l|l|l|l|}
\hline Model & $\mathbf{R}$ & $\begin{array}{l}\mathbf{R} \\
\text { Square }\end{array}$ & $\begin{array}{l}\text { Adjusted } \\
\text { R Square }\end{array}$ & $\begin{array}{l}\text { Std. } \\
\text { Error of } \\
\text { the } \\
\text { Estimate }\end{array}$ \\
\hline 1 & .767 & .588 & .572 & .42836 \\
\hline
\end{tabular}

Source: Survey data

\section{Conclusion and Recommendation}

Work-life balance is an important concept for employee and employers in any organizations. This study was carried out to investigate the factors affecting the work life balance of school teachers. This research concludes that workload, social support and childcare have great impact on work life balance. The data collected from school teachers both male and female was tested. The result revealed that there is a positive significant relationship between social support and work life balance. And workload and childcare were found to have negative significant relationship with work-life balance. Hence, the null hypotheses were rejected and all alternative hypotheses were accepted. Based on the multiple regression analysis the workload, social support and childcare have strong impact on work life balance. Findings of the research indicated that the school administrators pay considerable attention on work life balance of school teachers. In aligned with the findings of the study, the following recommendation can be made:

For the teachers: Follow the time management and set priorities, create a good social network from spouse, family and organization, use technology and use the facilities given by the organization in relation to work life balance.

For the organization: Create childcare facility in the school, conduct seminar on time management and work stress, be flexible in deadlines and workload and create the environment to maintain good relationship among supervisors, coworkers and subordinates.

\section{Suggestions for further research}

The main purpose of this study is to determine the impact of workload, social support and childcare on employees work life balance. This research accounts only $57 \%$ of the variability in 
WLB explained by these three variables and the balance $43 \%$ can be determined by other factors. But the researchers noted that some other factors like size of family, age of children, stress level, work environment, personal characteristics may impact on work life balance. Further research can consider the above factors and also the other sample area.

\section{References}

Anderson S E., Coffey B. S. \& Byerly, R. T. (2002) Formal organizational initiatives and informal workplace practices: Links to work-family conflict and job related outcomes. Journal of Management Vol28, pp787-788

Ayree, S. (1992) Antecedents and Outcomes of Work-Family Conflict among Married Professional Women Research, Vol. 1, pp. 279- 299.

Aryee, S., Srinivas, E. S., \& Tan, H. (2005) Rhythms of life: Antecedents and outcomes of work-family balance in employed parents Journal of Applied Psychology, Vol. 90, pp 132-146.

Bannur M. C. \& Patil R. M., (2015) Work Life Balance and Its impact on dimensions of Wellness: A Review of Literature. AARMSS International Journal of Management \& Social Science Research ISSN No: XXXX, Volume 1, Issue 1, August 2015.

Brough, P. \& Pears, J. (2004) Evaluating the Influence of the Type of Social Support on Job Satisfaction and Work Related Psychological Wellbeing.

Caven, V. \& Raiden, A. (2010) Work-life balance among architects. In Egbu, C. (Ed) Proceedings 26th Annual ARCOM Conference, 6-8 September 2010, Leeds, UK, Association of Researchers in Construction Management, 533-542.

Clarke M, Koch L, \& Hill E (2004) the work-family interfaces: Differentiating balance and fit. Family and Consumer Sciences Research Journal 33, 121-140.

Eisenberger, R., Huntington, R., Hutchison, S., \& Sowa, D. (1986) Perceived organizational support Journal of Vocational Behavior

Elliot, M. (2003) Work and family role strain among university employees. Journal of Family and Economic Issues 24, 157-180.

Fapohunda, T. M. (2014). An Exploration of the Effects of Work Life Balance on Productivity, Journal of Human Resources Management and Labor Studies June 2014, Vol. 2, No. 2, pp. 71-89 ISSN: 2333-6390 (Print), 23336404 (Online) Copyright C)

Fernando L. S. R \& Sareena Umma M. A. G. (2016) The Factors Affecting Work Life Balance of Married Working Women: With Special Reference to Bank of Ceylon Head office. Proceeding of the $6^{\text {th }}$ International Symposium, IntSym2016, SEUSL

Frone, M. R. (2003). Work-family balance Journal of Social Psychology, Vol39, pp 175-184

Gerson, K. (1993) No Man's Land: Men's Changing Commitments to Family and Work, New York: Basic Books.

Grzywacz, J.G \& Carlson D. S. (2007) Conceptualizing work-family balance: implications for practice and research. Adv. Dev. Hum Resource, Vol. 9, pp 455-471.

Kanthisree, G. (2013). Work Life Balance of Employees (A Study on Selected Public and Private Sector Undertakings). Journal of Social Science Information

Kumarasamy, M. A. P. M (2016) Individual, Organizational and Environmental Factors Affecting Work-Life Balance, Thesis Submitted to Othman Yeop Abdullah Graduate School of University Utara Malaysia in Fulfillment of the Requirement for the Doctor of Philosophy, New York, NY.

Kumar, K. P. A. \& Priyadarshini, R. G. (2018) Study to Measure the impact of Social Media Usage on Work-Life Balance, the $3^{\text {rd }}$ International Conference on Materials and Manufacturing Engineering 2018, 
IOP Publishing. Doi: 10.1088/1757899X/390/1/012045

Leavy, R. L. (1983) Social Support and Psychological Disorder, Journal of Personality and Social Psychology, 30, 166-184.

Leiter, M. P., \& Schaufeli, W. B. (1996) Consistency of the burnout construct across occupations. Journal of Personality and Social Psychology, 20, 120-134.

McCarthy, A., Cleveland, J. N., Hunter, S., Darcy, C., \& Grady, G. (2013) Employee work-life balance outcomes in Ireland: A multilevel investigation of supervisory support and perceived organizational support.

Obiageli, O.L., Uzochukwa, O.C. \& Ngozi, C.D., (2015). Work Life Balance and Employee Performance in Selected Commercial Banks in Lagos State. European Journal of Research and Reflection in Management sciences. Vol. 3 No. 4, 2015 ISSN 2056-5992

Omar M. K, Mohd, I. H. \& Ariffin, M. S. (2015). Workload, Role Conflict and Work-Life Balance among of an Enforcement Agency in Malaysia, International Journal of Business, Economics and Law, Vol. 8, Issue 2 (Dec.) ISSN 2289-1552 2015.

Opatha, H. H. D. N. P. (2009), Human Resource Management.

Osoian, C., Lazar, L. \& Ratiu, P. (2011) the benefits of implementing and supporting work-life balance policies in organizations. Sectorial Operational Programme Human Resources Development 2007-2013, Babes-Bolyai University, ClujNapoca, Romania.

Padma, S. \& Reddy, M. S. (2013), Impact of Child Care Responsibility on Work Life Balance (WLB) of School Teachers. International Journal of Advanced Research in Business Management and Administration Volume: 1 Issue: 1 08-Dec-2013, ISSN NO: 2348 -2354.
Pathiranage, T. \& Pathiranage, Y. L. (2020) Factors Affecting Work-Life Balance of Academics of Higher Education Institutes in Sri Lanka, January 2020, International Conference on Arts, Social Sciences, Humanities and Interdisciplinary Studies (ASSHIS17), Manila, Philippines

Perera, H. \& Opatha, H. H. D. N. P. (2014). Work Family Balance of Accounting Professional in Sri Lanka. $11^{\text {th }}$ International Conference on Business Management

Poulose S. \& Sudarsan N., (2014). Work Life Balance: A Conceptual Review. International Journal of Advances in Management and Economics MarchApril 2014 | Vol.3 | Issue 2|01-17. Available online at www.managementjournal.info

Reddy, N. K., Vranda, M. N., Ahmed, A. \& Siddaramu, B. (2010) Work-Life Balance among Married Women Employees. Indian J Psychol Med 2010 July-Dece.; 32(2): 12-18 DOI: $10.4103 / 0253-7176.78508$

Reiter, M. (2007) Work life balance: What do you mean? The ethical ideology underpinning appropriate application, The Journal of Applied Behavioral Sciences, 43, 273-294.

Ross, C. E. \& Murkowski, J. (1988) Childcare and emotional adjustment to wives' employment, Journal of Health and Social Behavior, 29: 2738

Samson A \& Sareena Umma M. A. G. (2019) Factors Influencing WorkFamily Balance of Professionals In The International Non-Governmental Organizations in the Eastern Province of Sri Lanka. Journal of Management Vol. 14, Issue. 2, 2019 ISSN: 13918230 13-26

Vogel, S. (2012) Overtime hours threaten work-life balance. Journal of Management and Organization

Wheatley, D. (2012). Work-life balance, travel-to-work, and the dual career household. Personnel Review, 41, 6, 813-831. 